\title{
Nitrogen cycling, profit margins and sweet corn yield under fall cover crop systems
}

\author{
Kelsey A. O’Reilly ${ }^{1}$, John D. Lauzon ${ }^{2}$, Richard J. Vyn ${ }^{3}$, and Laura L. Van Eerd ${ }^{1,4}$ \\ ${ }^{1}$ School of Environmental Sciences, University of Guelph Ridgetown Campus, Ridgetown, Ontario, \\ Canada NOP 2CO; ${ }^{2}$ School of Environmental Sciences, University of Guelph, Guelph, Ontario, Canada N1G 2W1; \\ and ${ }^{3}$ Department of Food, Agricultural and Resource Economics, University of Guelph Ridgetown Campus, \\ Ridgetown, Ontario, Canada NOP 2C0. Received 21 June 2011, accepted 30 November 2011.
}

\begin{abstract}
O'Reilly, K. A., Lauzon, J. D., Vyn, R. J. and Van Eerd, L. L. 2012. Nitrogen cycling, profit margins and sweet corn yield under fall cover crop systems. Can. J. Soil Sci. 92: 353-365. In order to improve $N$ best management practices in southwestern Ontario vegetable farming, the effect of cover crops on $\mathrm{N}$ dynamics in the fall and spring prior to sweet corn planting and during sweet corn season was assessed. The experiment was a split plot design in a fresh green pea - cover crop - sweet corn rotation that took place over 2 site-years at Bothwell and Ridgetown in 2006-2007 and 2007-2008, respectively. The main plot factor was fall cover crop type with five treatments including oat (Avena sativa $\mathrm{L}$.), cereal rye (Secale cereale L.), oilseed radish (OSR; Raphanus sativus L. var. oleoferus Metzg Stokes), mixture OSR plus cereal rye (OSR\&rye) and a no cover crop control. Compared with no cover crop, sweet corn profit margins were higher by $\$ 450$ $\mathrm{ha}^{-1}$ for oat at Bothwell and $\$ 1300$ and $\$ 760 \mathrm{ha}^{-1}$ for OSR and OSR\&rye, respectively, at Ridgetown. By comparing plant available $\mathrm{N}$ over the cover crop season, the cover crops tested were more effective at preventing $\mathrm{N}$ loss at Bothwell than at Ridgetown likely due to higher precipitation and sandier soil at Bothwell. Despite differences in site characteristics, cover crops did not result in increased plant available $\mathrm{N}$ compared with no-cover during the sweet corn season at either site, indicating that these cover crops will not provide an $\mathrm{N}$ credit to the following crop and growers should not modify $\mathrm{N}$ fertilizer applications based on cover crops.
\end{abstract}

Key words: Economics, catch crops, nitrate loss, oat, rye (cereal), oilseed radish, nitrogen budget

\begin{abstract}
O'Reilly, K. A., Lauzon, J. D., Vyn, R. J. et Van Eerd, L. L. 2012. Cycle de l'azote, marge de profit et rendement du maïs sucré dans un système cultural incluant un culture-abri. Can. J. Soil Sci. 92: 353-365. Les auteurs ont évalué l'incidence d'une culture-abri sur la dynamique du $\mathrm{N}$ à l'automne et au printemps, avant les semis et durant la période végétative du maïs sucré, en vue d'améliorer les pratiques exemplaires de gestion du $\mathrm{N}$ dans les régions maraîchères du sud-ouest de l'Ontario. L'expérience s'est déroulée selon un dispositif en tiroir, dans le cadre d'un assolement pois vert - culture-abri - maïs sucré et s'est déroulée à deux sites-années, soit à Bothwell et à Ridgetown, en 2006-2007 et 2007-2008, respectivement. La principale variable était la nature de la culture-abri. Les cinq traitements correspondaient à l'avoine (Avena sativa L.), au seigle (Secale cereale L.), au radis (Raphanus sativus L. var. oleoferus Metzg Stokes), à un mélange de radis et de seigle et à un témoin, soit l'absence de culture-abri. Comparativement au traitement témoin, la marge de profit du maïs sucré a augmenté de 450 \$ par hectare avec l'avoine, à Bothwell, ainsi que de $1300 \$$ et de $760 \$$ par hectare avec le radis et le mélange radis/seigle, respectivement, à Ridgetown. Quand on compare la quantité de $\mathrm{N}$ à la disposition des plantes durant la croissance de la culture-abri, on constate que les cultures testées préviennent mieux les pertes de $\mathrm{N}$ à Bothwell qu'à Ridgetown, sans doute à cause de précipitations plus abondantes et d'un sol plus sablonneux. En dépit des différences observées au niveau des particularités du site, la culture-abri n'a accru la quantité de $\mathrm{N}$ disponible pour les plantes à aucun des deux endroits pendant la saison de croissance du maïs sucré, comparativement au traitement témoin, signe que les cultures testées n'ajoutent pas du $\mathrm{N}$ au sol pour la culture subséquente et que les cultivateurs ne devraient pas modifier leurs applications d'engrais $\mathrm{N}$ en fonction de la culture-abri.
\end{abstract}

Mots clés: Économique, culture dérobée, perte de nitrates, avoine, seigle, radis, bilan azoté

With over 30000 ha of land in production, sweet corn is the most widespread field-grown vegetable crop in Canada. With approximately $50 \%$ of the national acreage, Ontario is the largest sweet corn producing province with a farm value of \$25.5 million in 2007 (Mailvaganam 2008). With such a large acreage, it is important that sweet corn production not only optimizes returns but

\footnotetext{
${ }^{4}$ Corresponding author (e-mail: lvaneerd@ridgetownc. uoguelph.ca)
}

also utilizes sustainable production practices. Cover crops are currently being incorporated into many production systems due to their ability to reduce soil erosion and runoff, increase soil aeration, water infiltration and soil organic matter, and improve nutrient cycling ( $\mathrm{Lu}$ et al. 2000; Hartwig and Ammon 2002; Snapp et al. 2005). Although some cover crops are

\footnotetext{
Abbreviations: OSR, oilseed radish; OSR\&Rye, mixture of oilseed radish and cereal rye; no-cover, no cover crop control treatment
} 
capable of reducing $\mathrm{NO}_{3}^{-}-\mathrm{N}$ losses from the soil during fallow periods (Wyland et al. 1996) and providing additional $\mathrm{N}$ to subsequent crops (Sainju and Singh 2008), these results have not been consistently observed. The effect of cover crops on $\mathrm{N}$ dynamics is not fully understood, especially in vegetable production.

Nitrogen is most prone to loss when mineral $\mathrm{N}$ is present in the soil and/or when crop residues mineralize during long periods of fallow (Weinert et al. 2002). Several vegetable crops, such as fresh pea, can leave fields without a crop for up to 9 mo of the year, resulting in a long time period for $\mathrm{N}$ losses to occur. Cover crops planted post-harvest can absorb and store $\mathrm{N}$ over the winter, thereby reducing soil $\mathrm{N}$ loss potential (Huntington et al. 1985). Beyond minimizing $\mathrm{N}$ loss, cover crops have been found to supply $20-55 \%$ of recovered $\mathrm{N}$ to subsequent crops (Malpassi et al. 2000). Based on a cover crop $\mathrm{N}$ content of $100 \mathrm{~kg} \mathrm{~N}^{-1}$ (Weinert et al. 2002), sweet corn acreage in Canada and $\mathrm{N}$ fertilizer cost of $\$ 1 \mathrm{~kg}^{-1}$, this would amount to a $\$ 0.6$ to $\$ 1.65$ million reduction in $\mathrm{N}$ fertilizer input costs for growers. However, in order to reduce $\mathrm{N}$ fertilizers without compromising yield, cover crop $\mathrm{N}$ mineralization should be in synchrony with $\mathrm{N}$ demand of the following crop (Vyn et al. 2000; Weinert et al. 2002).

Cover crops may be more advantageous in vegetable than field crop production due to longer fallow periods in which cover crops can immobilize N. Cover crop N accumulation and $\mathrm{N}$ availability to succeeding crops can be affected by cover crop species, precipitation, temperature, length of growing season and soil fertility (Stute and Posner 1993; Decker et al. 1994). Thus, it is imperative that research be conducted in Ontario to provide applicable cover crop recommendations to vegetable growers. Many growers are currently unwilling to modify $\mathrm{N}$ rates based on cover crop use due to a lack of information coupled with the relatively high value of most vegetable crops in relation to fertilizer costs. Therefore, to improve $\mathrm{N}$ best management practices in southwestern Ontario, the objectives of this study were to determine the impact of cover crops on: (1) soil and plant $\mathrm{N}$ contents over the rotation, (2) plant available $\mathrm{N}$ for sweet corn, and (3) sweet corn yield, biomass, and economics.

\section{MATERIALS AND METHODS}

\section{Experimental Design}

Research was conducted from 2006 to 2007 in a commercial production field near Bothwell, ON (lat. $42^{\circ} 66^{\prime} \mathrm{N}$, long. $81^{\circ} 95^{\prime} \mathrm{W}$ ) and from 2007 to 2008 at the University of Guelph Ridgetown Campus, Ridgetown, ON (lat. $42^{\circ} 46^{\prime} \mathrm{N}$, long. $81^{\circ} 89^{\prime} \mathrm{W}$ ). Soil types were a Brady Loamy Sand (Canada Experimental Farms Services 1957) and a Brookston Sandy Loam (Anonymous 1936) at Bothwell and Ridgetown, respectively (Table 1). Crops grown in the season prior to initiating the study were corn and soybeans at Bothwell and Ridgetown,
Table 1. Selected soil characteristics of experimental sites at Bothwell and Ridgetown, ON during 2006-2008

\begin{tabular}{lcc}
\hline Characteristic $^{\mathbf{z}}$ & Bothwell & Ridgetown \\
\hline pH & 6.3 & 5.9 \\
Soil texture & Loamy Sand & Sandy Loam \\
Sand:silt:clay (\%) & $82: 12: 6$ & $68: 21: 11$ \\
OM (\%) & 2.7 & 3.8 \\
Cation exchange capacity & 5.9 & 8.5 \\
$\quad\left(\right.$ Meq $\left.100 \mathrm{~g}^{-1}\right)$ & & \\
Preplant nutrients (mg kg & \\
Phosphorus & 21 & 20 \\
Potassium & 123 & 106 \\
Calcium & 700 & 1080 \\
Magnesium & 107 & 83 \\
\hline
\end{tabular}

${ }^{\mathbf{z}}$ Soil sample depth was $15 \mathrm{~cm}$.

respectively. The experiment was a split plot arrangement in a randomized complete block design with four replications in a fresh green pea-cover crop-sweet corn rotation. The main plot factor was fall cover crop type and the subplot factor was $\mathrm{N}$ fertilization of the sweet corn crop. The cover crop treatments included: a no cover crop control (no-cover), oat (cv. Manotick), cereal rye (cv. Common \#1), OSR (cv. Common \#1) (Ridgetown only), and a mixture of OSR + cereal rye (OSR\& Rye) planted with a drill at rates of 81, 67, 16 and $9+34$ $\mathrm{kg} \mathrm{ha}^{-1}$, respectively (Table 2). Due to space limitation, OSR was not planted at Bothwell. These cover crops were selected because of the availability of low-cost seed, their ease of establishment and growth, and grower experience, as they are typically grown in Ontario. The $\mathrm{N}$ fertilizer treatments were 0 and $140 \mathrm{~kg} \mathrm{~N} \mathrm{ha}^{-1}$ of calcium ammonium nitrate preplant hand-broadcast applied and incorporated prior to sweet corn planting. Each $\mathrm{N}$ subplot was $3.8 \mathrm{~m}$ (five $76 \mathrm{~cm}$ sweet corn rows) wide by $8 \mathrm{~m}$ long. Crop management and site preparation practices (Table 2) were as described in detail in O'Reilly et al. (2011). Air temperature and precipitation data were reported for Ridgetown and Petrolia, ON, which were both less than $30 \mathrm{~km}$ from the Bothwell site (Table 3). Weather data from Bothwell were incomplete and thus unreliable; however, annual precipitation and temperature trends at Ridgetown and Petrolia were similar to that observed at the Bothwell site.

After fresh green pea harvest, plots were disked and cultivated prior to cover crop planting on 2006 Aug. 04 and 2007 Jul. 19 at Bothwell and Ridgetown (Table 2). At Bothwell and Ridgetown, plant available $\mathrm{N}$ at pea harvest was 94 and $210 \mathrm{~kg} \mathrm{~N}^{-1}$, respectively, with 54 and $64 \%$ from soil mineral $\mathrm{N}$ and the remainder in pea shoots and pods. Due to sufficient soil nutrient levels at both sites (Table 1), no fertilizer was applied prior to cover crop planting. At Ridgetown, no-cover plots were sprayed on 2007 Sep. 25 and Oct. 17 with diquat and glyphosate at 300 and $810 \mathrm{~g}$ a.i. ha ${ }^{-1}$, respectively, to control weeds (Table 2; O'Reilly et al. 2011). The following spring, to kill the rye cover crops, the entire 


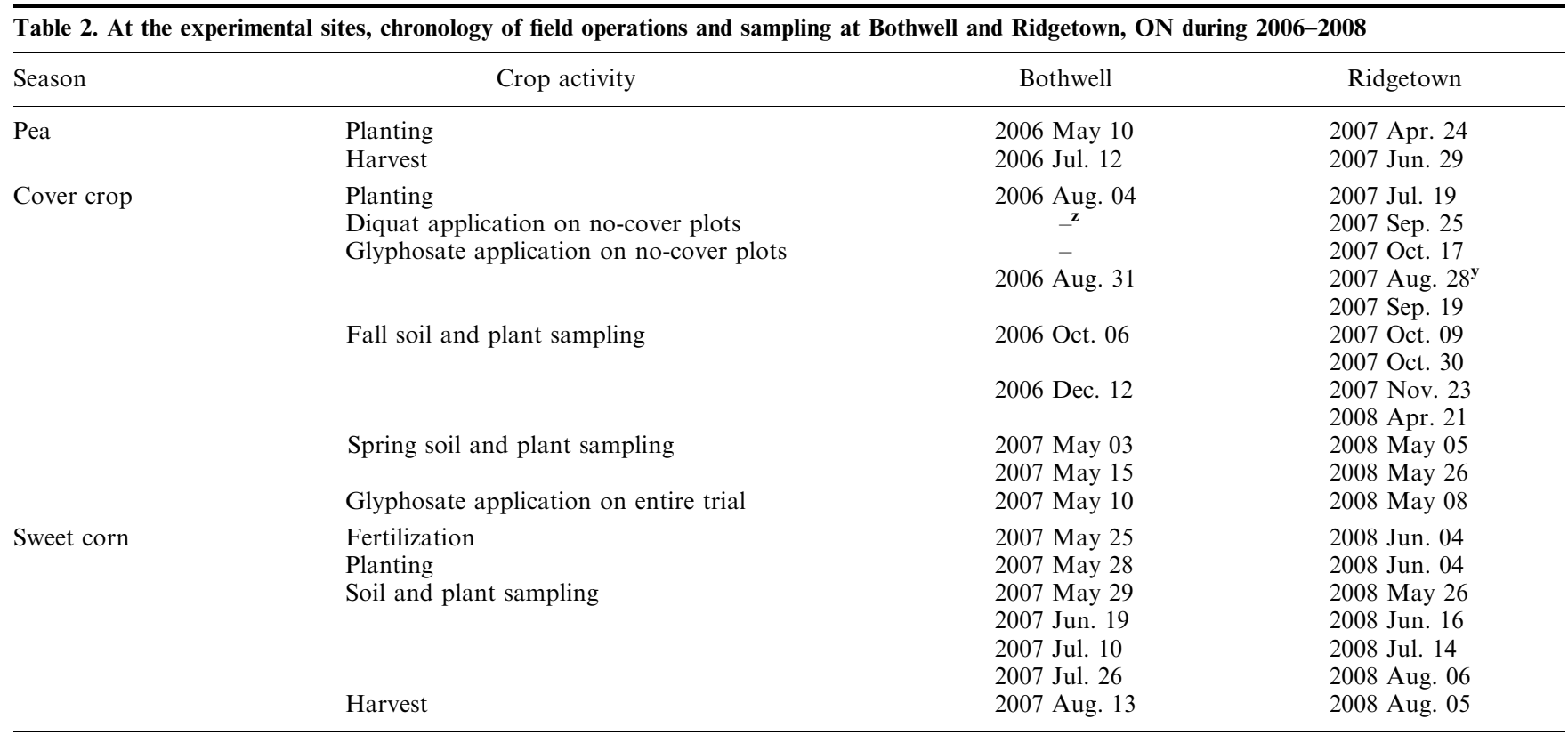

${ }^{\mathrm{z}}$ Due to an absence of weeds, no herbicide application was made. ${ }^{\mathbf{y}}$ Soil samples only.

trial was sprayed with glyphosate at $810 \mathrm{~g}$ a.i. $\mathrm{ha}^{-1}$ on 2007 May 08 and 2008 May 10 at Bothwell and Ridgetown, respectively. After fertilizer application, the entire trial was disked and cultivated before sweet corn (cv. Temptation) planting at 59300 plants ha ${ }^{-1}$ on 2007 May 28 and 2008 Jun. 04 at Bothwell and Ridgetown, respectively. Typical Ontario production practices for sweet corn were followed for fertilization for all nutrients other than $\mathrm{N}$, pest, and other field management [Ontario Processing Vegetable Growers (OPVG) 2007]. Sweet corn was hand harvested on 2007 Aug. 13 and 2008 Aug. 05 at Bothwell and Ridgetown, respectively (Table 2).

\section{Soil Measurements}

Site soil characteristics were determined according to Carter and Gregorich (2008) on a composite soil sample taken from at least twenty $3.5-\mathrm{cm}$-diameter cores to 15-cm depth (Table 1). Over the rotation (Table 2) soil mineral $\mathrm{N}$ content $\left(\mathrm{NO}_{3}^{-}-\mathrm{N}\right.$ and $\left.\mathrm{NH}_{4}^{+}-\mathrm{N}\right)$ from each subplot was determined on composite soil samples taken from at least five 3.5 -cm-diameter cores at depths of 0-30, 30-60 and 60-90 cm. In the field, soil cores were divided into $30-\mathrm{cm}$ increments, homogenized by depth, sealed in plastic bags, and put into a cooler for transport. Samples were immediately stored frozen $\left(-20^{\circ} \mathrm{C}\right)$ and sent frozen to an Ontario accredited laboratory for soil mineral $\mathrm{N}$ quantification as described by Maynard et al. (2008) via a $2 \mathrm{M} \mathrm{KCl}$ extraction and using an autoanalyzer (Technicon Auto Analyzer II; Tarrytown; New York, NY) with cadmium reduction method and phenate method for $\mathrm{NO}_{3}^{-}-\mathrm{N}$ and $\mathrm{NH}_{4}^{+} \mathrm{N}$, respectively. For the $0-$ to $60-\mathrm{cm}$ and $60-$ to $90-\mathrm{cm}$ depths, soil mineral $\mathrm{N}$ was the sum of $\mathrm{NO}_{3}^{-}-\mathrm{N}$ and $\mathrm{NH}_{4}^{+}-\mathrm{N}$ expressed as $\mathrm{kg} \mathrm{N}^{-1}$ based on soil bulk density (Carter and Gregorich 2008). Results for soil mineral $\mathrm{N}$ only were presented because differences in soil mineral $\mathrm{N}$ were due primarily to differences in $\mathrm{NO}_{3}^{-}-\mathrm{N}$ as $\mathrm{NH}_{4}^{+} \mathrm{N}$ was largely unaffected by treatment.

\section{Crop Measurements}

Approximately every $3 \mathrm{wk}$ in the fall and twice in May, cover crop and weed, if present, biomass samples were taken from a different randomly selected quadrat within the main plot as described by O'Reilly et al. (2011). In the no-cover treatment, plant biomass and $\mathrm{N}$ content were weeds, when present. Cover crop and weed biomass was collected regardless of whether the plant was alive or dead.

Five sweet corn plants from each subplot were collected every 3 wk up to and including harvest. At sweet corn harvest, $6 \mathrm{~m}$ of the centre two rows of each subplot were hand harvested. Harvested ears were separated into marketable and non-marketable categories based on industry standards (OPVG 2007) as well as a stringent examination of each ear, which involved opening the husk of each ear and examining ear size, kernel development and insect damage. If any insect damage or poor kernel development was found, the ear was considered non-marketable. This assessment was done for insect and disease research also being conducted at the sites. The weight and number of marketable and non-marketable ears were recorded. A representative sample of five cobs and five corn plants per subplot were weighed fresh, dried at $60^{\circ} \mathrm{C}$, and weighed dry. Cob $\mathrm{N}$ was defined as total $\mathrm{N}$ content 


\begin{tabular}{|c|c|c|c|c|c|c|c|}
\hline \multirow[b]{2}{*}{ Month } & \multicolumn{3}{|c|}{ Petrolia } & \multicolumn{4}{|c|}{ Ridgetown } \\
\hline & 2006 & 2007 & $30-y r$ mean & 2006 & 2007 & 2008 & $30-y r$ mean \\
\hline & \multicolumn{7}{|c|}{ Temperature $\left({ }^{\circ} \mathrm{C}\right)$} \\
\hline Jan. & 0.8 & -3 & -5.3 & 2 & -1.4 & -1.7 & -3.7 \\
\hline Feb. & -2.8 & -8.2 & -4.4 & -1.2 & -7.2 & -3.7 & -2.4 \\
\hline Mar. & 1.4 & 2.4 & 1 & 3.1 & 4.2 & 0.5 & 2 \\
\hline Apr. & 9 & 6.9 & 7.2 & 12.5 & 10.5 & 12.1 & 7.1 \\
\hline May & 14.9 & 15.4 & 13.8 & 14.2 & 17.9 & 12.1 & 13.6 \\
\hline Jun. & 18.7 & 20.7 & 18.8 & 18.2 & 21.6 & 20.1 & 18.8 \\
\hline Jul. & 22.8 & 20.7 & 21.5 & 21.8 & 23.6 & 22.1 & 21.5 \\
\hline Aug. & 20.5 & 21 & 20.6 & 19.8 & 23.4 & 19.8 & 20.6 \\
\hline Sep. & 15.5 & 18.1 & 16.6 & 17.2 & 18.6 & 22.6 & 16.8 \\
\hline Oct. & 8.9 & 14.8 & 10.3 & 12.6 & 16.9 & 12.8 & 10.6 \\
\hline Nov. & 5.3 & 3 & 3.9 & 6.1 & 4.7 & 4.2 & 4.8 \\
\hline Dec. & 2 & -2.3 & -2.2 & 3.1 & -1.2 & -2.4 & -1.2 \\
\hline Jan. & 98 & 107 & 68 & $\begin{array}{c}\text { Total precipitation }(\mathrm{mm}) \\
101\end{array}$ & 132 & 71 & 61 \\
\hline Feb. & 80 & 32 & 53 & 72 & 21 & 107 & 54 \\
\hline Mar. & 73 & 48 & 66 & 66 & 103 & 116 & 60 \\
\hline Apr. & 60 & 56 & 85 & 67 & 72 & 45 & 73 \\
\hline May & 83 & 51 & 79 & 84 & 79 & 64 & 77 \\
\hline Jun. & 46 & 37 & 89 & 55 & 64 & 170 & 82 \\
\hline Jul. & 92 & 24 & 76 & 98 & 83 & 83 & 93 \\
\hline Aug. & 94 & 134 & 82 & 76 & 101 & 26 & 105 \\
\hline Sep. & 86 & 34 & 98 & 110 & 42 & 140 & 93 \\
\hline Oct. & 154 & 47 & 73 & 132 & 70 & 31 & 55 \\
\hline Nov. & 105 & 50 & 85 & 56 & 56 & 88 & 75 \\
\hline Dec. & 60 & 140 & 80 & 111 & 92 & 142 & 67 \\
\hline Total & 1029 & 760 & 935 & 1028 & 915 & 1083 & 895 \\
\hline
\end{tabular}

within sweet corn cob, grain and husk. Corn shoot $\mathrm{N}$ was defined as total $\mathrm{N}$ content in leaves and stems. Total plant $\mathrm{N}$ was the sum of shoot and cob $\mathrm{N}$.

A representative sample of cover crop, weed, and sweet corn above-ground plant tissue was weighed, a subsample dried, moisture content determined and ground to pass through a 2-mm screen using a Wiley mill. Plant tissue $\mathrm{N}$ and $\mathrm{C}$ contents were determined by combustion (Rutherford et al. 2008) using a LECO $\mathrm{N}$ determinator and a LECO C determinator (Leco Corporation, St. Joseph, MI), respectively. At each sample date, carbon to nitrogen ratio was based on total $\mathrm{N}$ and $\mathrm{C}$ content in plant tissue for all cover crop treatments and for the OSR\&Rye treatment was a weighted average based on biomass. Plant available $\mathrm{N}$ was quantified as the sum of soil mineral $\mathrm{N}$ in the top 60 $\mathrm{cm}$ and the total $\mathrm{N}$ content of the above-ground plant tissue. During the cover crop season, plant available $\mathrm{N}$ in the no-cover treatment was soil mineral $\mathrm{N}$ in the top $60 \mathrm{~cm}$ and, if present, weed $\mathrm{N}$ content.

\section{Statistical Analyses}

There were no differences among treatments in how the no-cover treatment was sampled and analyzed except for cover crop plant sampling because no cover crop was planted in the no-cover treatment. At Ridgetown, when present, weed plant biomass was collected and analyzed for $\mathrm{N}$ content. If no weed biomass was collected, then the no-cover treatment was not included in the data analyses of plant data. Data were subjected to ANOVA using the MIXED procedure of SAS Version 9.1 after testing for normality and homogeneity of variance (SAS Institute, Inc., Cary, NC). Means were separated using the Tukey-Kramer adjustment test at the 0.05 probability level. A subplot analysis was used for sweet corn biomass, soil $\mathrm{N}$, plant $\mathrm{N}$ and plant available $\mathrm{N}$ analyses, where cover crop type and $\mathrm{N}$ rate were the main plot and subplot factors, respectively (Bowley 1999). A subplot analysis was not required for the cover crop season because $\mathrm{N}$ rate was not yet a factor. In all analyses, comparisons were made between treatments at each date. Non-orthogonal contrasts were used to compare the no-cover and the other cover crop treatments, as well as between the OSR treatments and the no-cover control and the cereal treatments. Outliers were determined using the boxplot method (Tukey 1977). When outliers were present, they were removed from the analysis only if the results were significantly affected by their removal. All data from each site were analyzed separately due to the differences in treatments, sampling dates, and physical and environmental factors between the 2 site-years.

\section{Economic Analyses}

The economic analyses for this study calculated profit margins over cover crop and $\mathrm{N}$ fertilizer costs and 
assessed for differences in margins among treatments as described in O'Reilly et al. (2011). These profit margins, which only take into account costs that vary among treatments, were calculated as total revenues less costs associated with cover crops. Total revenues were determined based on the yield for each plot and the provincial average price of fresh market sweet corn in 2007 (Mailvaganam 2008). The costs associated with cover crops include seed costs, the cost of hiring a custom applicator to plant the cover crops, and, for treatments that included rye, the cost of herbicide control in the spring, which included the cost of the herbicide product and custom application of the herbicide (Fletcher 2007).

Fisher's LSD was used to determine statistically significant differences in profit margins between cover crop treatments at each site with and without $\mathrm{N}$ fertilizer, while regression analysis was used to determine whether the use of each cover crop had a significant impact on profit margins relative to no-cover. The regression equation was:

$$
\begin{aligned}
P M= & a+b^{*} \text { Oat }+c^{*} \text { Rye }+d^{*} O S R+e^{*}(\text { OSR\&Rye }) \\
& +f^{*} \text { Fert }+g^{*} \text { Weedy }
\end{aligned}
$$

where $P M$ is the profit margin over cover crop and fertilizer costs; Oat, Rye, OSR, and OSR\&Rye are categorical variables representing the use of each cover crop; Fert is a categorical variable equal to 1 if fertilizer was applied to the plot, to account for the effect that fertilizer application has on profit margin relative to treatments with no fertilizer applied; Weedy is a categorical variable that accounts for the difference in profit margin for plots that were not kept weed-free relative to those that were weeded (O'Reilly et al. 2011); and $a, b, c$, $d, e, f$, and $g$ are parameters to be estimated. With all independent variables being categorical, this implies that the regression equation must be linear in nature.

\section{RESULTS AND DISCUSSION}

\section{Cover Crop Season - August to May}

\section{Plant N Content}

At Bothwell, due to the relative absence of weed biomass in all plots (O'Reilly et al. 2011), weeds in the no-cover plots were only sampled on May 03 and had less above-ground plant $\mathrm{N}$ than the planted cover crops (Fig. 1). On all dates except December, rye, oat, and OSR\&Rye did not differ among each other in plant $\mathrm{N}$ content (Fig. 1).

In 2007 at Ridgetown, plant $\mathrm{N}$ content in weeds in the no-cover was not different from the cereals in September and oat in early October (Fig. 2). By late October and November sample dates, the application of herbicides in the no-cover lowered weed biomass (O'Reilly et al. 2011) and $\mathrm{N}$ content (Fig. 2) compared with other cover crop treatments on earlier sample dates.

At Ridgetown on the November sample date, OSR and OSR\&Rye had higher plant $\mathrm{N}$ content than the cereal cover crops (Fig. 2); OSR reached maturity producing viable seed. At both sites, by the last fall sample date, although oat and OSR were dead due to freezing temperatures, between 75 to $240 \mathrm{~kg} \mathrm{~N}^{-1}$ was immobilized in cover crop biomass for all planted cover crops. Immobilized $\mathrm{N}$ in plant tissue is much less susceptible to loss through leaching or denitrification compared with soil mineral N. In the following spring at Ridgetown, similar to at Bothwell, there was no difference in plant $\mathrm{N}$ content among planted cover crops, which contained 40 to $110 \mathrm{~kg} \mathrm{~N} \mathrm{ha}^{-1}$ (Fig. 2). Thus, at both sites, in 8 of the 11 sample times, there were no differences among planted cover crops in the quantity of $\mathrm{N}$ immobilized in plant tissue.

Vyn et al. (2000) also found no difference in cover crop $\mathrm{N}$ content among rye, oat and OSR sampled in late fall in a 3-yr study in southern Ontario. Similar to Bothwell in December and Ridgetown in October, Wagger (1989)

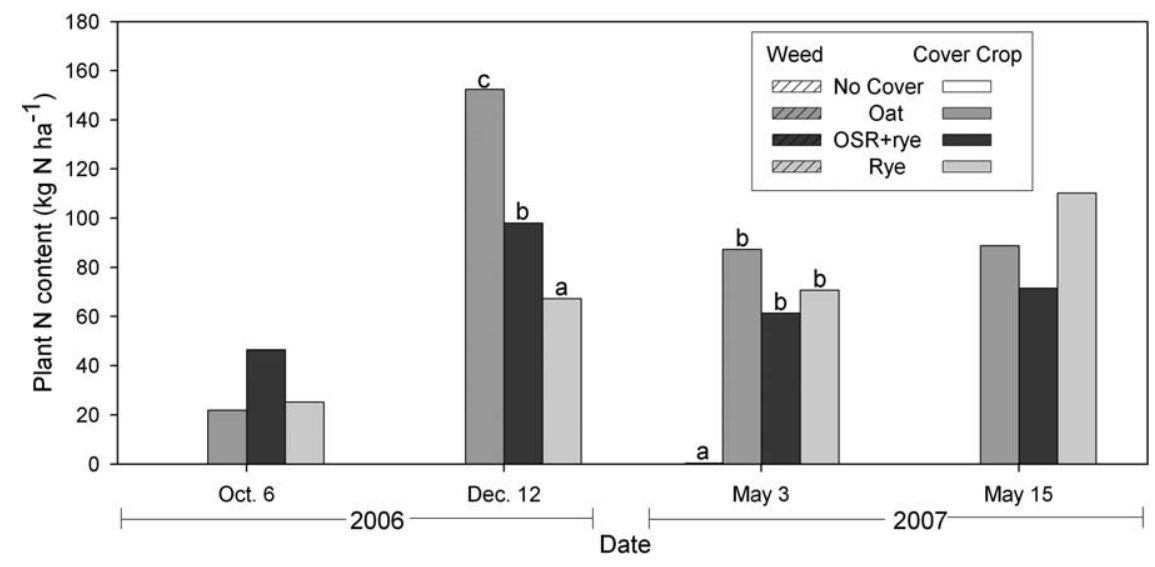

Fig. 1. Cover crop (solid bars) and weed (hashed bars) above-ground N content at Bothwell in 2006-2007. If present, different letters within a sampling date indicate significant differences between treatments $(P<0.05)$ based on Tukey-Kramer means separation. OSR\&Rye, oilseed radish plus rye. Cover crops were planted on 2006 Aug. 04, cover crops were frost killed by mid-November, and rye growth terminated with glyphosate applied on 2007 May 10. 


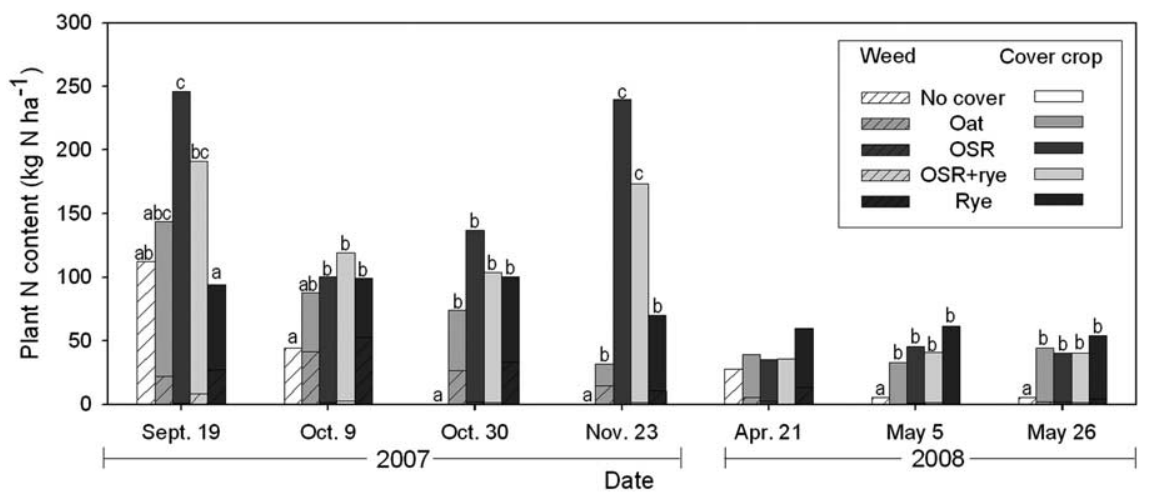

Fig. 2. Cover crop (solid bars) and weed (hashed bars) above-ground N content at Ridgetown in 2007-2008. If present, different letters within a sampling date indicate significant differences between treatments in total plant $\mathrm{N}$ content $(P<0.05)$ based on TukeyKramer means separation. OSR, oilseed radish; OSR\&Rye, oilseed radish plus rye. Cover crops were planted on 2007 Jul. 19, no cover crop plots were treated with herbicides to control weeds on 2007 Sep. 25 and 2007 Oct. 17, cover crops were frost killed by early November, and rye growth terminated with glyphosate applied on 2008 May 08.

and Weinert et al. (2002) observed rye and Brassica cover crop $\mathrm{N}$ content of 114 to $140 \mathrm{~kg} \mathrm{~N}^{-1}$. Likewise, when greater than $3000 \mathrm{~kg} \mathrm{ha}^{-1}$ of shoot biomass was produced, cover crops have been found to accumulate over $100 \mathrm{~kg} \mathrm{~N} \mathrm{ha}^{-1}$ (Weinert et al. 2002).

At Ridgetown, OSR and OSR\&Rye had higher biomass and plant $\mathrm{N}$ content compared with that observed by Vyn et al. (2000) and Weinert et al. (2002). The high plant $\mathrm{N}$ content in OSR and OSR\&Rye treatments at Ridgetown was likely due to the fact that plants reached physiological maturity and set viable seed. Plant $\mathrm{N}$ content of both OSR treatments was not inconsistent with canola at maturity, where plant $\mathrm{N}$ content, including dropped leaves, was $>300 \mathrm{~kg} \mathrm{~N} \mathrm{ha}^{-1}$ (assuming plant density of 100 plants $\mathrm{m}^{-2}$ ) (Svecnjak and Rengel 2006).

Vyn et al. (2000) suggested that low soil $\mathrm{NO}_{3}^{-}-\mathrm{N}$ after wheat harvest restricted the growth of non-leguminous cover crops. At pea harvest, there was at least $94 \mathrm{~kg} \mathrm{~N}$ $\mathrm{ha}^{-1}$ of soil mineral $\mathrm{N}$ in the $0-$ to $60-\mathrm{cm}$ depth, which was considerably higher than that observed after wheat (Vyn et al. 2000) and likely contributed to higher cover crop biomass and $\mathrm{N}$ content in our study. Moreover, the earlier harvest of pea and cover crop planting in our system compared with wheat (Vyn et al. 2000), resulted in more growing degree days for more cover crop growth (Table 2 and 3). Earlier sown cover crops tend to have higher $\mathrm{N}$ content in the fall than later sown covers (Allison et al. 1998). Plant N content in cover crops in the spring was consistent with Schomberg et al. (2006).

\section{Soil Mineral $N$}

At Bothwell in October, all of the cover crop treatments had lower soil mineral $\mathrm{N}$ than no-cover in the top $60 \mathrm{~cm}$ (Table 4). In December, cover crop treatments were rye $<$ oat $<$ OSR \&Rye $=$ no-cover for soil mineral $\mathrm{N}$ levels at Bothwell in the $0-$ to $60-\mathrm{cm}$ depth. Low soil mineral $\mathrm{N}$ under the rye treatment may be because rye was not frost killed in November like all other cover crops; therefore, rye may still have been growing and taking up $\mathrm{N}$ in the intervening period up to the midDecember sampling date. Soil mineral $\mathrm{N}$ was likely higher in OSR\&Rye than oat and rye treatment due to rapid decomposition of OSR leaf and root tissues. After a killing frost, Weinert et al. (2002) also found that rye had lower soil mineral $\mathrm{N}$ levels than a no-cover and a Brassica cover crop.

Similar to Bothwell, the top $60 \mathrm{~cm}$ at Ridgetown, all cover crops tended to have lower soil mineral $\mathrm{N}$ in the fall than no-cover (Table 4). By the last sample date in November at Ridgetown, all planted cover crops except oat had at least $64 \%$ less soil mineral $\mathrm{N}$ than the nocover. Similarly, Vyn et al. (2000) found that OSR, oat and rye cover crops reduced soil $\mathrm{NO}_{3}^{-}-\mathrm{N}$ compared with no-cover in November.

In the spring at both sites, there were no differences in soil mineral $\mathrm{N}$ among cover crop treatments at 0 - to $60-\mathrm{cm}$ soil depth, except for on May 03 at Bothwell, where soil mineral $\mathrm{N}$ was $33 \%$ lower in rye compared with the no-cover (Table 4). The lack of differences among the cover crops in soil mineral $\mathrm{N}$ in the following spring was consistent with Vyn et al. (1999).

By the last fall sample date at both sites, soil mineral $\mathrm{N}$ in the planted cover crops was lower or not different than no-cover in the 60- to $90-\mathrm{cm}$ depth (Table 4). Considering that all planted cover crops had lower soil mineral $\mathrm{N}$ compared with the no-cover at earlier fall sample dates, it is possible that the lack of difference between planted cover crops and no-cover may be due to decomposition of cover crop roots. During the spring, in the $60-$ to $90-\mathrm{cm}$ soil depth at both sites, rye was the only cover crop to have lower soil mineral $\mathrm{N}$ levels than no-cover (Table 4).

Taking into consideration that the underlying principle regarding the risk of $\mathrm{N}$ loss is that mineral $\mathrm{N}$ availability $=$ vulnerability for losses (Addiscott et al. 


\begin{tabular}{|c|c|c|c|c|c|c|c|c|c|c|c|c|c|c|}
\hline \multirow[b]{3}{*}{ Date } & \multicolumn{7}{|c|}{$0-60 \mathrm{~cm}$} & \multicolumn{7}{|c|}{$60-90 \mathrm{~cm}$} \\
\hline & \multirow{2}{*}{$\begin{array}{c}\text { No-cover } \\
\text { soil mineral } \\
\mathrm{N}\left(\mathrm{kg} \mathrm{N} \mathrm{ha}^{-1}\right)\end{array}$} & \multirow{2}{*}{$\begin{array}{c}\text { Soil mineral } \mathrm{N} \\
P \text { value }\end{array}$} & No-cover & Oat & $\mathrm{OSR}^{\mathbf{z}}$ & OSR\&Rye & Rye & \multirow{2}{*}{$\begin{array}{c}\text { No-cover } \\
\text { soil mineral } \\
\mathrm{N}\left(\mathrm{kg} \mathrm{N} \mathrm{ha}^{-1}\right)\end{array}$} & \multirow{2}{*}{$\begin{array}{c}\text { Soil mineral } \mathrm{N} \\
P \text { value }\end{array}$} & \multirow{2}{*}{\multicolumn{2}{|c|}{ No-cover }} & OSR & \multirow{2}{*}{$\begin{array}{l}\text { OSR\&Rye } \\
\text { to no-cover ( }\end{array}$} & \multirow[t]{2}{*}{ Rye } \\
\hline & & & \multicolumn{5}{|c|}{ Soil mineral $\mathrm{N}$ relative to no-cover $(\%)$} & & & & & USK & & \\
\hline \multicolumn{15}{|c|}{ Bothwell (2006-2007) } \\
\hline Aug. 31 & 58.1 & 0.034 & $100 b$ & $82 a b$ & - & $64 a$ & $77 a b$ & 14.5 & 0.741 & 100 & 105 & - & 94 & 83 \\
\hline Oct. 06 & 61.9 & $<0.001$ & $100 b$ & $45 a$ & - & $52 a$ & $50 a$ & 25.6 & $<0.001$ & $100 c$ & $46 b$ & - & $29 a$ & $22 a$ \\
\hline Dec. 12 & 30.3 & $<0.001$ & $100 c$ & $81 b$ & - & $104 c$ & $48 a$ & 8.0 & 0.002 & $100 b$ & $48 a$ & - & $91 b$ & $96 b$ \\
\hline May 03 & 46.3 & 0.003 & $100 b$ & $110 b$ & - & $117 b$ & $67 a$ & 13.3 & $<0.001$ & $100 b$ & $113 b$ & - & $86 b$ & $50 a$ \\
\hline May 15 & 47.8 & 0.042 & $100 a b$ & $121 b$ & - & $110 a b$ & $74 a$ & - & - & - & - & - & - & - \\
\hline \multicolumn{15}{|c|}{ Ridgetown (2007-2008) } \\
\hline Aug. 28 & 204 & $<0.001$ & $100 c$ & $73 b$ & $39 a$ & $41 a$ & $88 b$ & 35.4 & 0.023 & $100 b$ & $82 a$ & $52 a$ & $47 a$ & $100 b$ \\
\hline Sep. 19 & 123 & 0.005 & $100 a b$ & $118 b$ & $41 a$ & $40 a$ & $70 a b$ & 14.8 & 0.009 & $100 b$ & $76 a b$ & $43 a$ & $46 a$ & $55 a b$ \\
\hline Oct. 09 & 148 & $<0.001$ & $100 c$ & $72 b c$ & $33 a$ & $25 a$ & $44 a b$ & 17.7 & 0.001 & $100 b$ & $69 a$ & $49 a$ & $49 a$ & $47 a$ \\
\hline Oct. 30 & 155 & $<0.001$ & $100 c$ & $73 b$ & $25 a$ & $22 a$ & $31 a$ & 24.1 & $<0.001$ & $100 b$ & $62 a$ & $25 a$ & $28 a$ & $50 a$ \\
\hline Nov. 23 & 172 & $<0.001$ & $100 b$ & $87 b$ & $36 a$ & $23 a$ & $31 a$ & 19.5 & 0.005 & $100 b$ & $80 a b$ & $56 a$ & $53 a$ & $65 a$ \\
\hline Apr. 21 & 77.1 & 0.132 & 100 & 69 & 146 & 107 & 110 & 86 & 0.414 & 100 & 66 & 101 & 82 & 81 \\
\hline May 05 & 91.8 & 0.092 & 100 & 81 & 140 & 126 & 74 & 21.8 & 0.146 & 100 & 53 & 78 & 93 & 51 \\
\hline May 26 & 89.1 & 0.058 & 100 & 90 & 159 & 118 & 87 & 18.3 & 0.037 & $100 b$ & $67 a b$ & $93 a b$ & $80 a b$ & $51 a$ \\
\hline
\end{tabular}

${ }^{\mathrm{z}}$ OSR, oilseed radish; OSR\&Rye, oilseed radish plus rye. At Bothwell, no OSR treatment was planted due to limited space.

$a-c$ Within rows, for a given soil depth means followed by different letters, if present, were significantly different $(P<0.05)$ based on Tukey-Kramer means separation. 
1991), the general trend of lower soil mineral $\mathrm{N}$ content with cover crops compared with no-cover suggests cover crops lower the risk of $\mathrm{N}$ loss. Evidence that cover crops lower soil mineral $\mathrm{N}$ and $\mathrm{N}$ losses is consistent with the literature (Jackson et al. 1993; Lu et al. 2000; Vyn et al. 2000; Weinert et al. 2002).

\section{Plant Available N}

At Bothwell, no difference in plant available $\mathrm{N}$ was seen between cover crop treatments 1 mo after planting (Table 5). In October, plant available $\mathrm{N}$ did not differ between the cover crops and no-cover, although OSR\&Rye had higher plant available $\mathrm{N}$ than oat. The lack of differences in plant available $\mathrm{N}$ indicates that $\mathrm{N}$ loss through leaching or denitrification may not have been substantial prior to October and was consistent with soil mineral $\mathrm{N}$ content. The lack of apparent $\mathrm{N}$ loss prior to October is consistent with lower precipitation compared with 30-yr mean (Table 3). In December, planted cover crops had 50 to $147 \mathrm{~kg} \mathrm{~N}^{-1}$ higher plant available $\mathrm{N}$ than no-cover (Table 5). Considering that plant available $\mathrm{N}$ is the sum of soil mineral $\mathrm{N}$ in the $0-$ to $60-\mathrm{cm}$ depth and cover crop plant tissue, the lower plant available $\mathrm{N}$ in no-cover may be due to $\mathrm{N}$ leached beyond $60 \mathrm{~cm}$, denitrified, or immobilized by December.

At Ridgetown from September through November, plant available $\mathrm{N}$ was similar for no-cover and cover crops (Table 5). The lack of differences in plant available $\mathrm{N}$ suggests that there was little $\mathrm{N}$ lost over the fall, as observed soil moisture conditions were not conducive to leaching and/or denitrification, which was consistent with $46 \mathrm{~mm}$ lower precipitation during September and October of 2007 compared with the 30-yr mean (Table 3). In addition, weed growth in the no-cover during September and early October may explain the lack of differences in plant available $\mathrm{N}$ among treatments as the weeds acted as a cover crop immobilizing $\mathrm{N}$.

Total plant available $\mathrm{N}$ in early and mid May, at Bothwell, was higher for the cover crops than no-cover; however, there were no differences between the planted cover crops (Table 5). Spring plant available $N$ values provide a rough estimate of the ability of cover crops to reduce $\mathrm{N}$ loss over the winter. Therefore, oat, OSR\&Rye and rye cover crops prevented the loss of approximately 96,76 , and $97 \mathrm{~kg} \mathrm{~N} \mathrm{ha}^{-1}$, respectively, in comparison to no-cover (Table 5).

At Ridgetown in the spring, plant available $\mathrm{N}$ was unaffected by cover crop treatments (Table 5), suggesting that either there was little $\mathrm{N}$ loss over the winter and spring or that $\mathrm{N}$ loss was the same in all treatments. However, at Ridgetown, plant available $\mathrm{N}$ in the nocover treatment was numerically lower than the cover crops tested, for all spring sampling dates, which was similar to trends observed at Bothwell. In addition to coarser soil texture at Bothwell, the larger differences between planted cover crops and no-cover at Bothwell than at Ridgetown was likely due to considerably higher precipitation (approximately $153 \mathrm{~mm}$ ) during the cover crop growing season from August to May 2006-2007 at Bothwell compared with Ridgetown (Table 3). High precipitation at Bothwell increased soil moisture and conditions conducive to $\mathrm{N}$ leaching or denitrification.

\section{Sweet Corn Season - June to August}

\section{Plant N Content}

Cover crop treatment had no effect on sweet corn plant $\mathrm{N}$ content over the growing season $(P \geq 0.09)$ or at harvest $(P \geq 0.167)$ at either site and there was no cover crop by $\mathrm{N}$ rate interaction ( $P>0.05$; data not shown).

\begin{tabular}{|c|c|c|c|c|c|c|}
\hline & No-cover & Oat & $\operatorname{OSR}^{\mathbf{y}}$ & OSR\&Rye & Rye & \\
\hline Date & \multicolumn{5}{|c|}{ Plant available $\mathrm{N}\left(\mathrm{kg} \mathrm{N}_{\mathrm{Na}}^{-1}\right)$} & $P$ value \\
\hline \multicolumn{7}{|c|}{ Bothwell (2006-2007) } \\
\hline Aug. 31 & 58 & 47 & - & 35 & 45 & 0.066 \\
\hline Oct. 06 & $62 a b$ & $50 a$ & - & $78 b$ & $56 a b$ & 0.034 \\
\hline Dec. 12 & $30 a$ & $177 d$ & - & $130 c$ & $82 b$ & $<0.001$ \\
\hline May 03 & $48 a$ & $139 b$ & - & $115 b$ & $102 b$ & 0.001 \\
\hline May 15 & $48 a$ & $144 b$ & - & $125 b$ & $146 b$ & 0.001 \\
\hline \multicolumn{7}{|c|}{ Ridgetown (2007-2008) } \\
\hline Aug. 28 & $205 b$ & $147 b$ & $80 a$ & $81 a$ & $180 b$ & $<0.001$ \\
\hline Sep. 19 & 238 & 277 & 303 & 245 & 166 & 0.198 \\
\hline Oct. 09 & 192 & 197 & 150 & 168 & 168 & 0.641 \\
\hline Oct. 30 & 156 & 187 & 187 & 142 & 149 & 0.382 \\
\hline Nov. 23 & $180 a b$ & $178 a b$ & $317 b$ & $229 a b$ & $123 a$ & 0.026 \\
\hline Apr. 21 & 116 & 120 & 217 & 149 & 149 & 0.053 \\
\hline May 05 & 106 & 111 & 141 & 131 & 116 & 0.251 \\
\hline May 26 & 114 & 124 & 165 & 137 & 129 & 0.491 \\
\hline
\end{tabular}

${ }^{\mathbf{z}}$ Plant available $\mathrm{N}$ was the sum of soil mineral $\mathrm{N}$ in the top $60 \mathrm{~cm}$ and total $\mathrm{N}$ content of above-ground cover crop and/or weed plant tissue. ${ }^{\mathrm{y}}$ OSR, oilseed radish; OSR\&Rye, oilseed radish plus rye. At Bothwell, no OSR treatment was planted due to limited space.

$a-d$ Within rows, means followed by different letters, if present, were significantly different $(P<0.05)$ based on Tukey-Kramer means separation. 
At Bothwell, sweet corn plant $\mathrm{N}$ content was higher with than without $\mathrm{N}$ fertilizer from June through to harvest $(P \leq 0.042$; data not shown). At Bothwell, shoot $\mathrm{N}$ at harvest was higher in the $140 \mathrm{~kg} \mathrm{~N}^{-1}$ treatment than the $0 \mathrm{~kg} \mathrm{~N}$ ha ${ }^{-1}$ treatment $(P=0.03)$, but cob $\mathrm{N}$ content was unaffected $(P=0.06)$. At Ridgetown, sweet corn plant $\mathrm{N}$ content throughout the growing season was numerically higher in fertilized versus non-fertilized plots; however, this difference was significant only in July and at harvest $(P \leq 0.001)$. At harvest, sweet corn shoot and cob $\mathrm{N}$ content was higher with $\mathrm{N}$ fertilizer than without $(P \leq 0.002)$, which was consistent with Mullins et al. (1999) who found fertilization increased sweet corn plant $\mathrm{N}$ content at harvest. There was neither cover crop nor $\mathrm{N}$ effect, nor cover crop by $\mathrm{N}$ interaction effect for the proportion of plant $\mathrm{N}$ in the cob (i.e., harvest $\mathrm{N}$ index), which was 68 and $76 \%$ at Bothwell and Ridgetown, respectively. Thus, neither cover crop nor $\mathrm{N}$ fertilizer affected the allocation of $\mathrm{N}$ between vegetative and reproductive tissues.

Sweet corn total plant $\mathrm{N}$ at harvest ranged from 88 to 116 and from 170 to $205 \mathrm{~kg} \mathrm{~N}^{-1}$ at Bothwell and Ridgetown, respectively. Inconsistent effects of cover crops on both sweet and field corn plant $\mathrm{N}$ have been noted in the literature (Bundy and Andraski 2005; Isse et al. 1999; Teasdale and Abdul-Baki 1998; Vyn et al. 1999). Similar to our results, Isse et al. (1999) found that forage radish (Raphanus raphanistrum L.), ryegrass (Lolium multiflorum L.) and red clover (Trifolium pratense L.) did not affect sweet corn shoot or cob $\mathrm{N}$ content at harvest.

\section{Soil Mineral N}

With soil mineral $\mathrm{N}$, there were no cover crop by $\mathrm{N}$ interactions $(P>0.05)$ at any depth $(0-30,30-60$, and 60-90 cm). Throughout the sweet corn season, the fertilized plots had 1.5 to 3 times higher soil mineral $\mathrm{N}$ than the non-fertilized plots in the 0 - to $60-\mathrm{cm}$ depth at both sites and in the 60- to $90-\mathrm{cm}$ depth at Bothwell (data not shown; $P \leq 0.013$ ). At Ridgetown from 60 to $90 \mathrm{~cm}$, soil mineral $\mathrm{N}$ was higher in the fertilized than non-fertilized treatments only in July (data not shown).

Throughout the sweet corn season at both sites and both depths, oat and OSR\&Rye did not affect soil mineral $\mathrm{N}$ levels compared with no-cover (Table 6). However, at Bothwell, rye had significantly lower soil mineral $\mathrm{N}$ levels than no-cover in the 0 - to $60-\mathrm{cm}$ depth in June and late July as well as in May, early and late July at the $60-$ to $90-\mathrm{cm}$ depth. During the sweet corn season at Ridgetown, cover crops generally had no effect on soil mineral $\mathrm{N}$ in the top $60 \mathrm{~cm}$ (Table 6). In the 60- to 90-cm soil depth at Ridgetown, soil mineral $\mathrm{N}$ was unaffected by cover crops compared with the nocover with the exception of soil mineral $\mathrm{N}$ being lower under rye than no-cover in May (Table 6). The observed trend of net $\mathrm{N}$ immobilization of rye was consistent with Vyn et al. (1999).
Regardless, at both sites in both depths, soil mineral N was not higher with cover crops compared with nocover, suggesting that the cover crops did not provide an $\mathrm{N}$ credit to the sweet corn crop. In the following growing season, the lack of increase in soil mineral $\mathrm{N}$ in nonleguminous cover crop treatments compared with nocover was consistent with other research (Wagger 1989; Vyn et al. 1999). It is possible that net $\mathrm{N}$ mineralization of cover crops did not match up with sweet corn $\mathrm{N}$ demand. For instance, although highly dependent on cover crop plant chemical composition (Wagger 1989; Janssen 1996) and environmental conditions (Miller et al. 1994), mineralization of cover crops can be rapid, within $5 \mathrm{~d}$ of incorporation (Jackson et al. 1993). At both sites cover crops were incorporated a few days prior to sweet corn planting.

\section{Plant Available N}

At both sites, plant available $\mathrm{N}$ was higher in the fertilized than non-fertilized treatments (Table 7) but there were no cover crop by $\mathrm{N}$ rate interactions $(P>0.05)$. At Bothwell, there were no differences between cover crop treatments, except in late July when rye had lower plant available $\mathrm{N}$ than no-cover (Table 7). Lower plant available $\mathrm{N}$ in rye, regardless of $\mathrm{N}$ fertilization rate, suggests net $\mathrm{N}$ immobilization. At Ridgetown in May, at sweet corn planting, plant available $\mathrm{N}$ was higher in OSR than no-cover and oat (Table 7). However, for the remainder of the sweet corn season, cover crops had no effect on plant available N. Therefore, although the cover crop treatments produced more plant available $\mathrm{N}$ than no-cover before sweet corn planting, this did not translate into higher plant available $\mathrm{N}$ levels during sweet corn growth. The general lack of cover crop effect and lack of cover crop by $\mathrm{N}$ rate interaction effect on plant available $\mathrm{N}$ during sweet corn season indicates that growers do not need to decrease or increase $\mathrm{N}$ fertilizer with the tested cover crops in their rotation. No relevant literature was found on the effects of cover crops on corn plant available $\mathrm{N}$.

\section{Yield and Profit Margins}

Sweet corn shoot biomass was unaffected by cover crop treatment at both sites over the sweet corn season $(P \geq 0.152$; data not shown). Mean sweet corn shoot biomass was 167 and $103 \mathrm{~kg} \mathrm{ha}^{-1}$ on 2007 May 29 and 2008 May 26, respectively, and 2890 and $2950 \mathrm{~kg}$ ha $^{-1}$ at harvest on 2007 Aug. 13 and 2008 Aug. 05, respectively, at Bothwell and Ridgetown, respectively. At Bothwell, $\mathrm{N}$ treatment affected sweet corn shoot biomass only in early July, with higher sweet corn biomass in the fertilized compared with the unfertilized treatment (data not shown). At Ridgetown, $\mathrm{N}$ treatment had no effect on sweet corn shoot biomass production at any time during the sweet corn season, likely due to high plant available $\mathrm{N}$ over the growing season (data not shown). Other research has also shown that fertilization 
does not necessarily lead to increased sweet corn biomass or plant populations (Dyck and Liebman 1994; Mullins et al. 1999; Teasdale et al. 2008). Similarly, others have found that neither cover crops (Teasdale et al. 2008; Burgos and Talbert 1996) nor N treatment (Isse et al. 1999) had an effect on sweet corn biomass.

At Bothwell, there was a cover crop by $\mathrm{N}$ treatment interaction for total yield; however, there were no interactions and no cover crop effect for marketable sweet corn yield (Table 8). At Bothwell, total yield did not differ among cover crop treatments where $\mathrm{N}$ fertilizer was applied, but total yield was higher for oat and OSR\&Rye than the no-cover with no $\mathrm{N}$ fertilizer applied. The reason for the cover crop by $\mathrm{N}$ rate interaction is unknown, but it may be that high $\mathrm{N}$ fertility in the fertilized plots masked any cover crop effect. At Bothwell, the $140 \mathrm{~kg} \mathrm{~N}$ ha ${ }^{-1}$ treatment produced $4.1 \mathrm{Mg}$ ha $^{-1}$ more marketable yield than the $0 \mathrm{~kg} \mathrm{~N} \mathrm{ha}{ }^{-1}$ treatment. Although cover crops had no effect on marketable sweet corn yields (Table 8), marketable yields followed similar trends as total yields. The 2007 growing season was a comparably hot and dry year (Table 3), which contributed to the low yields observed in our trial and across much of the province, with mean marketable yields of 9.5 and $12 \mathrm{Mg} \mathrm{ha}^{-1}$, respectively (Mailvaganam 2008).

At Ridgetown, there was no cover crop by $\mathrm{N}$ treatment interaction for total or marketable yield. The $140 \mathrm{~kg} \mathrm{~N} \mathrm{ha}{ }^{-1}$ treatment produced higher total sweet corn yields than no $\mathrm{N}$ fertilizer treatment; however, no differences were seen in marketable yield between the two $\mathrm{N}$ treatments (Table 8). Cover crop had no effect on total or marketable yields at this site. Total yields at Ridgetown were high due to a large number of plants having small non-marketable second cobs. Adequate summer rainfall (Table 3 ) at Ridgetown in 2008 may also have contributed to high marketable yields compared with Bothwell in 2007.

Higher plant available $\mathrm{N}$ during the sweet corn season at Ridgetown than Bothwell (Table 7) provides some explanation as to why cover crops affected sweet corn yield in the $0 \mathrm{~kg} \mathrm{~N} \mathrm{ha}^{-1}$ but not the $140 \mathrm{~kg} \mathrm{~N}^{-1}$ treatment at Bothwell and why there was no cover crop effect with or without $\mathrm{N}$ fertilizer at Ridgetown. In general, the positive effect of $\mathrm{N}$ fertilizer on total and marketable yield at Bothwell, and in total yield at Ridgetown was consistent with other research (Burket et al. 1997; Mullins et al. 1999; Griffin et al. 2000; Cline and Silvernail 2002; Teasdale et al. 2008). Similar to our study, Mullins et al. (1999), Burket et al. (1997), and Griffin et al. (2000) observed variable weather during their studies, including hot dry years. As well, with the exception of the study by Teasdale et al. (2008), which was conducted on loamy sand soil, the other studies (Burket et al. 1997; Mullins et al. 1999; Griffin et al. 2000; Cline and Silvernail 2002) occurred predominately 


\begin{tabular}{|c|c|c|c|c|c|c|c|c|c|}
\hline \multirow[b]{2}{*}{ Date } & No-cover & Oat & $\operatorname{OSR}^{y}$ & OSR\&Rye & Rye & \multirow[b]{2}{*}{$P$ value } & $0 \mathrm{~kg} \mathrm{~N}$ ha $^{-1}$ & $140 \mathrm{~kg} \mathrm{~N} \mathrm{ha}^{-1}$ & \multirow[b]{2}{*}{$P$ value } \\
\hline & \multicolumn{5}{|c|}{ Plant available $\mathrm{N}\left(\mathrm{kg} \mathrm{N} \mathrm{ha}^{-1}\right)$} & & \multicolumn{2}{|c|}{ Plant available $\mathrm{N}\left(\mathrm{kg} \mathrm{N} \mathrm{ha}^{-1}\right)$} & \\
\hline & \multicolumn{9}{|c|}{ Bothwell } \\
\hline May 29 & 110 & 117 & - & 123 & 111 & 0.885 & $81.6 a$ & $149 b$ & 0.001 \\
\hline Jun. 19 & 222 & 170 & - & 186 & 140 & 0.099 & $129 a$ & $229 b$ & $<0.001$ \\
\hline Jul. 10 & 175 & 186 & - & 139 & 131 & 0.376 & $108 a$ & $208 b$ & 0.002 \\
\hline Jul. 26 & $192 b$ & $171 a b$ & - & $164 a b$ & $121 a$ & 0.024 & $103 a$ & $221 b$ & $<0.001$ \\
\hline \multirow[t]{2}{*}{ Aug. 13} & 153 & 202 & - & 167 & 208 & 0.251 & $104 a$ & $261 b$ & $<0.001$ \\
\hline & \multicolumn{9}{|c|}{ Ridgetown } \\
\hline May 26 & $69.3 a$ & $78.3 a$ & $124 b$ & $97 a b$ & $74.2 a$ & 0.018 & - & - & - \\
\hline Jun. 16 & 202 & 172 & 263 & 246 & 236 & 0.142 & $156 a$ & $291 b$ & $<0.001$ \\
\hline Jul. 14 & 190 & 241 & 202 & 190 & 209 & 0.583 & $148 a$ & $264 b$ & $<0.001$ \\
\hline Aug. 06 & 145 & 141 & 207 & 191 & 167 & 0.064 & $114 a$ & $225 b$ & $<0.001$ \\
\hline
\end{tabular}

${ }^{\mathrm{z}}$ Plant available $\mathrm{N}$ was the sum of soil mineral $\mathrm{N}$ in the top $60 \mathrm{~cm}$ and total $\mathrm{N}$ content of above-ground corn plant tissue.

${ }^{\mathbf{y}}$ OSR, oilseed radish; OSR\&Rye, oilseed radish plus rye; Pre-plant broadcast incorporated calcium ammonium nitrate. At Bothwell, no OSR treatment was planted due to space limitations.

$a, b$ Within a row for a given treatment group, means followed by different letters, if present, were different $(P<0.05)$ based on Tukey-Kramer means separation.

on silt loam soils and therefore were less sandy than the soils in our study.

Similar to our study, effects of cover crops on sweet corn yield showed mixed and often contrasting results depending on site-year (Carrera et al. 2004; Malik et al. 2008). Other research indicates that yield was generally unaffected by cover crops (Burket et al. 1997) or depending on the cover crop, yield was either positively or negatively affected (Burgos and Talbert 1996; Galloway and Weston 1996).

Across all sites and similar to yields, the profit margins tended to be higher with than without $\mathrm{N}$ fertilizer (Tables 9 and 10). The results of the pairwise comparisons indicate that the profit margins for sweet corn at Bothwell were highest for oat cover crop, with and without $\mathrm{N}$ fertilizer (Table 9). At Ridgetown, OSR had the highest profit margins. At both sites with or without $\mathrm{N}$ fertilizer, all cover crops had profit margins that were as high as or higher than no-cover based on pairwise comparisons (Table 9).

Similarly, based on regression analysis, the impacts of the cover crops on profit margins varied across the sites.
At Bothwell, only oat had a statistically significant effect on profit margins, increasing margins by about $\$ 450$ $\mathrm{ha}^{-1}$ compared with no-cover (Table 10). At Ridgetown, both OSR and OSR\&Rye cover crops increased, compared with no-cover, profit margins by $\$ 1300$ and $\$ 760 \mathrm{ha}^{-1}$, respectively. Similar to yield, $\mathrm{N}$ fertilizer application, compared with the no $\mathrm{N}$ fertilizer treatment, significantly increased profit margins by $\$ 662$ $\mathrm{ha}^{-1}$ and $\$ 902 \mathrm{ha}^{-1}$ at Bothwell and Ridgetown, respectively, while margins were lower for weedy plots than for weed-free plots (Table 10; O'Reilly et al. 2011).

Overall, the results of the economic analyses imply that profitability of sweet corn production with the use of various cover crops may vary under different growing conditions. As such, none of the cover crops performed consistently better from an economic perspective across all site-years. Creamer et al. (1996) also found that various cover cropping systems were more profitable than no-cover at different locations. In our sweet corn study at each site, none of the cover crops lowered profit margins compared with no-cover, and, depending on the site-year, oat, OSR and OSR\&Rye produced the highest

Table 8. Effect of cover crop and nitrogen fertilizer on sweet corn total and marketable yield at Bothwell and Ridgetown, ON, in 2007 and 2008 , respectively

\begin{tabular}{|c|c|c|c|c|c|c|c|}
\hline \multirow{2}{*}{$\begin{array}{l}\mathrm{N} \text { fertilizer rate } \\
\left(\mathrm{kg} \mathrm{N} \mathrm{ha}^{-1}\right)\end{array}$} & \multicolumn{4}{|c|}{ Total yield $\left(\mathrm{Mg} \mathrm{ha}^{-1}\right)$} & \multirow{2}{*}{$\begin{array}{l}\text { Marketable yield } \\
\left(\mathrm{Mg} \mathrm{ha}^{-1}\right)\end{array}$} & \multirow{2}{*}{$\begin{array}{l}\text { Total yield } \\
\left(\mathrm{Mg} \mathrm{ha}^{-1}\right)\end{array}$} & \multirow{2}{*}{$\begin{array}{l}\text { Marketable yield } \\
\left(\mathrm{Mg} \mathrm{ha}^{-1}\right)\end{array}$} \\
\hline & No-cover & Oat & OSR\&Rye & Rye & & & \\
\hline & \multicolumn{4}{|c|}{ Bothwell } & & \multicolumn{2}{|c|}{ Ridgetown } \\
\hline 0 & $6.5 a$ & $11.4 b c$ & $11.4 b c d$ & $6.7 a b$ & $5.4 a$ & $40.0 a$ & 22.4 \\
\hline 140 & $12.2 c d$ & $15.2 d$ & $14.0 c d$ & $13.7 c d$ & $9.5 b$ & $45.9 b$ & 19.5 \\
\hline$P$ value & \multicolumn{4}{|c|}{0.038} & 0.001 & 0.001 & 0.310 \\
\hline
\end{tabular}

${ }^{\mathrm{z}}$ OSR\&Rye, oilseed radish plus rye. At Bothwell, no OSR treatment was planted due to limited space.

$a-d$ Within a given yield group means followed by different letters, if present, were significantly different $(P<0.05)$ based on Tukey-Kramer means separation. 
Table 9. Effect of cover crop and $\mathbf{N}$ fertilizer on profit margins in fresh market sweet corn at Bothwell and Ridgetown, ON, in 2007 and 2008, respectively

\begin{tabular}{|c|c|c|c|c|}
\hline \multirow[b]{3}{*}{ Cover crop } & \multicolumn{4}{|c|}{$\mathrm{N}$ fertilizer rate $\left(\mathrm{kg} \mathrm{N} \mathrm{ha}^{-1}\right)$} \\
\hline & \multicolumn{2}{|c|}{0} & \multicolumn{2}{|c|}{140} \\
\hline & \multicolumn{4}{|c|}{ Profit margins $\left(\$ \mathrm{ha}^{-1}\right)$} \\
\hline & Bothwell & Ridgetown & Bothwell & Ridgetown \\
\hline No-cover & $940 b c$ & $4430 b c$ & $1630 b$ & $5420 a b$ \\
\hline Oat & $1380 a$ & $3770 c$ & $2090 a$ & $5130 b$ \\
\hline $\mathrm{OSR}^{\mathrm{z}}$ & - & $6200 a$ & - & $6250 a$ \\
\hline OSR\&Rye & $1240 a b$ & $5390 a b$ & $1620 b$ & $5970 a b$ \\
\hline Rye & $800 c$ & $4700 b c$ & $1660 b$ & $6220 a$ \\
\hline
\end{tabular}

${ }^{\mathrm{z}}$ OSR, oilseed radish; OSR\&Rye, oilseed radish plus rye. At Bothwell, no OSR treatment was planted due to limited space.

$a-c$ Within columns, means followed by different letters were different based on Fisher's LSD means separation $(P<0.05)$.

\begin{tabular}{|c|c|c|}
\hline \multirow[b]{2}{*}{ Parameter } & \multicolumn{2}{|c|}{ Parameter estimates } \\
\hline & Bothwell & Ridgetown \\
\hline$a$ & $1050 * * \pm 101$ & $7260^{* *} \pm 292$ \\
\hline$b$ & $455^{* *} \pm 118$ & $-477 \pm 349$ \\
\hline$c$ & $-49 \pm 118$ & $535 \pm 349$ \\
\hline$d$ & - & $1300 * * \pm 349$ \\
\hline$e$ & $146 \pm 118$ & $759 * \pm 349$ \\
\hline$f$ & $662 * * \pm 83$ & $902 * * \pm 220$ \\
\hline$g$ & $-203^{*} \pm 83$ & $-5580 * * \pm 220$ \\
\hline
\end{tabular}

${ }^{\mathrm{z}}$ OSR, oilseed radish; OSR\&Rye, oilseed radish plus rye; Fert, effect of applying $140 \mathrm{~kg} \mathrm{~N}^{-1}$ pre-plant broadcast incorporated calcium ammonium nitrate fertilizer on profit margins compared with zero $\mathrm{N}$ fertilizer; Weedy, difference in profit margin for plots that were not kept weed-free relative to those that were (O'Reilly et al. 2010). At Bothwell, no OSR treatment was planted due to limited space.

**, * Parameter estimates, with standard error of the mean, were significantly different from zero when compared with the no cover crop control treatment at $P<0.01$ and $P<0.05$, respectively; others not significant.

profit margins. Similarly, Carrera et al. (2004) observed that cover crop increased profitability of no-till sweet corn. Among several studies, the profitability of cover crops in horticultural production varied, with the majority of unprofitable cover crops being the result of decreased main crop yield compared with no-cover (Lu et al. 2000), which was not observed at either site in our study. Therefore, costs should not be a limiting factor for growers to incorporate cover crops into sweet corn rotation, especially because the economic analyses in this study considered the cost of hiring a custom applicator to plant the cover crop and to apply the herbicide to control the rye cover crop in the spring and profits were significantly higher or not different than the no-cover.

Although the cover crops tested were effective at conserving $\mathrm{N}$ over the fall and winter periods compared with the no-cover, cover crops do not provide a significant $\mathrm{N}$ credit to the following sweet corn crop. Regardless of the purpose of cover crop implementation, the cover crops tested did not decrease sweet corn yields or profit margins, where profit margins included the cost of planting and managing the cover crops. In fact, oat, OSR and OSR\&Rye increased profit margins by $\$ 450$ $\mathrm{ha}^{-1}$ to $\$ 1,300 \mathrm{ha}^{-1}$ compared with no-cover. Hence, the cover crops tested were feasible and profitable options to include in sweet corn production.

\section{ACKNOWLEDGEMENTS}

Funding for this project was provided in part by Ontario Ministry of Agriculture, Food and Rural Affairs, Agriculture and Agri-Food Canada through the Agricultural Adaptation Council CORD IV program, Fresh Vegetable Growers of Ontario, as well as in-kind analyses from Agri-Food Laboratories Ltd., and A\&L Laboratories Inc. Thanks are extended to Mike Zink, Jess Turnbull, Elaine Roddy and Anne Verhallen for their technical expertise.

Addiscott, T. M., Whitmore, A. P. and Powlson, D. S. 1991. Farming, fertilizers and the nitrate problem. CAB International, Wallingford, UK. 170 pp.

Allison, M. F., Armstrong, M. J., Jaggard, K. W. and Todd A. D. 1998. Integration of nitrate cover crops into sugarbeet (Beta vulgaris) rotations. I. Management and effectiveness of nitrate cover crops. J. Agric. Sci. 130: 53-60.

Anonymous. 1936. Soil map, County of Kent, Province of Ontario, Canada. 1:63,360:1. The Experimental Farms Branch, Ottawa, ON.

Bowley, S. 1999. A hitchhiker's guide to statistics in plant biology. Any Old Subject Books, Guelph, ON. 250 pp.

Bundy, L. G. and Andraski, T. W. 2005. Recovery of fertilizer nitrogen in crop residues and cover crops on an irrigated sandy soil. Soil Sci. Soc. Am. J. 69: 640-648.

Burgos, N. R. and Talbert, R. E. 1996. Weed control and sweet corn (Zea mays var. rugosa) response in a no-till system with cover crops. Weed Sci. 44: 355-361.

Burket, J. Z., Hemphill, D. D. and Dick, R. P. 1997. Winter cover crops and nitrogen management in sweet corn and broccoli rotations. HortScience 32: 664-668.

Canada Experimental Farms Services. 1957. Soil survey of Lambton County. Experimental Farm Service, Canada Dept. of Agriculture and the Ontario Agricultural College, Guelph, ON.

Carrera, L. M., Abdul-Baki, A. A. and Teasdale, J. R. 2004. Cover crop management and weed suppression in no-tillage sweet corn production. HortScience 39: 1262-1266.

Carter, M. R. and Gregorich, E. G. 2008. Soil sampling and methods of analysis. 2nd ed. CRC Press, Inc., Boca Raton, FL. 1225 pp.

Cline, G. R. and Silvernail, A. F. 2002. Effects of cover crops, nitrogen, and tillage on sweet corn. HortTechnology 12: $118-125$. 
Creamer, N. G., Bennett, M. A., Stinner, B. R. and Cardina, J. 1996. A comparison of four processing tomato production systems differing in cover crop and chemical inputs. J. Am. Soc. Hortic. Sci. 121: 559-568.

Decker, A. M., Clark, A. J., Meisinger, J. J., Mulford, F. R. and McIntosh, M. S. 1994. Legume cover crop contributions to no-tillage corn production. Agron. J. 86: 126-135.

Dyck, E. and Liebman, M. 1994. Soil fertility management as a factor in weed-control - The effect of crimson clover residue, synthetic nitrogen-fertilizer, and their interaction on emergence and early growth of lambsquarters and sweet corn. Plant Soil 167: 227-237.

Fletcher, C. 2007. Provincial survey of custom farmwork charged in 2006. OMAFRA Factsheet 07-019. Queen's Printer for Ontario. ISSN 1198-712X [Online] Available: http://www.omafra.gov.on.ca/english/busdev/facts/07-019a.htm [2011 Jun. 07].

Galloway, B. A. and Weston, L. A. 1996. Influence of cover crop and herbicide treatment on weed control and yield in notill sweet corn (Zea mays L.) and pumpkin (Cucurbita maxima Duch.). Weed Technol. 10: 341-346.

Griffin, T., Liebman, M. and Jemison, J. 2000. Cover crops for sweet corn production in a short-season environment. Agron. J. 92: 144-151.

Hartwig, N. L. and Ammon, H. U. 2002. Cover crops and living mulches. Weed Sci. 50: 688-699.

Huntington, T. G., Grove, J. H. and Frye, W. W. 1985. Release and recovery of nitrogen from winter annual cover crops in no-till corn production. Commun. Soil Sci. Plant Anal. 16: 193-211.

Isse, A. A., MacKenzie, A. F., Stewart, K., Cloutier, D. C. and Smith, D. L. 1999. Cover crops and nutrient retention for subsequent sweet corn production. Agron. J. 91: 934-939.

Jackson, L. E., Wyland, L. J. and Stivers, L. J. 1993. Winter cover crops to minimize nitrate losses in intensive lettuce production. J. Agric. Sci. 121: 55-62.

Janssen, B. H. 1996. Nitrogen mineralization in relation to $\mathrm{C}: \mathrm{N}$ ratio and ecomposability of organic materials. Plant Soil 181: $39-45$.

Lu, Y., Watkins, K., Teasdale, J. R. and Abdul-Baki, A. A. 2000. Cover crops in sustainable food production. Food Rev. Int. 16: 121-157.

Mailvaganam, S. 2008. Area, production and farm value of specified commercial vegetable crops, Ontario, 2007. [Online] Available: http://www.omafra.gov.on.ca/english/stats/hort/ veg_m07.htm [2011 Jun. 07].

Malik, M. S., Norsworthy, J. K., Culpepper, A. S., Riley, M. B. and Bridges, W. 2008. Use of wild radish (Raphanus raphanistrum) and rye cover crops for weed suppression in sweet corn. Weed Sci. 56: 588-595.

Malpassi, R. N., Kaspar, T. C., Parkin, T. B., Cambardella C. A. and Nubel, N. A. 2000. Oat and rye root decomposition effects on nitrogen mineralization. Soil Sci. Soc. Am. J. 64: 208-215.

Maynard, D. G., Kalra, Y. P. and Crumbaugh, J. A. 2008. Nitrate and exchangeable ammonium nitrogen. Pages 71-80 in M. R. Carter and E. G. Gregorich. eds. Soil sampling and methods of analysis. 2nd ed. CRC Press, Boca Raton FL.
Miller, M. H., Beauchamp, E. G. and Lauzon, J. D. 1994. Leaching of nitrogen and phosphorus from the biomass of three cover crop species. J. Environ. Qual. 23: 267-272.

Mullins, C. A., Straw, R. A., Pitt, B. J., Onks, D. O., Mullen, M. D., Reynolds, J. and Kirchner, M. 1999. Response of selected sweet corn cultivars to nitrogen fertilization. HortTechnology 9: 32-35.

O'Reilly, K. A., Robinson, D. E., Vyn, R. J. and Van Eerd, L. L. 2011. Weed populations, sweet corn yield, and economics following fall cover crops. Weed Technol. 25: 374-384.

Ontario Processing Vegetable Growers. 2007. Information handbook. London, ON. $141 \mathrm{pp}$.

Rutherford, P. M., McGill, W. B., Arocena, J. M. and Figueiredo, C. T. 2008. Total nitrogen. Pages 239-250 in M. R. Carter and E. G. Gregorich, eds. Soil sampling and methods of analysis 2nd ed. CRC Press Inc., Boca Raton, FL. Sainju, U. M. and Singh, B. P. 2008. Nitrogen storage with cover crops and nitrogen fertilization in tilled and nontilled soils. Agron. J. 100: 619-627.

Schomberg, H. H., Endale, D. M., Calegari, A., Peixoto, R., Miyazawa, M. and Cabrera, M. L. 2006. Influence of cover crops on potential nitrogen availability to succeeding crops in a southern piedmont soil. Biol. Fertility Soils 42: 299-307.

Snapp, S. S., Swinton, S. M., Labarta, R., Mutch, D., Black J. R., Leep, R., Nyiraneza, J. and O'Neil, K. 2005. Evaluating cover crops for benefits, costs and performance within cropping system niches. Agron. J. 97: 322-332.

Stute, J. K. and Posner, J. L. 1993. Legume cover crop options for grain rotations in Wisconsin. Agron. J. 85: 1128-1132.

Svecnjak, Z. and Rengel, Z. 2006. Nitrogen utilization efficiency in canola cultivars at grain harvest. Plant Soil 283: 299-307.

Teasdale, J. R. and Abdul-Baki, A. A. 1998. Comparison of mixtures vs. monocultures of cover crops for fresh-market tomato production with and without herbicide. HortScience 33: $1163-1166$.

Teasdale, J. R., Abdul-Baki, A. A. and Park, Y. B. 2008. Sweet corn production and efficiency of nitrogen use in high cover crop residue. Agron. Sustain. Devel. 28: 559-565.

Tukey, J. W. 1977. Exploratory data analysis. Addison-Wesley Publ. Co., Reading, MA. 688 pp.

Vyn, T. J., Faber, J. G., Janovicek, K. J. and Beauchamp, E. G. 2000. Cover crop effects on nitrogen availability to corn following wheat. Agron. J. 92: 915-924.

Vyn, T. J., Janovicek, K. J., Miller, M. H. and Beauchamp E. G. 1999. Soil nitrate accumulation and corn response to preceding small-grain fertilization and cover crops. Agron. J. 91: 17-24.

Wagger, M. G. 1989. Time of desiccation effects on plant composition and subsequent nitrogen release from several winter annual cover crops. Agron. J. 81: 236-241.

Weinert, T. L., Pan, W. L., Moneymaker, M. R., Santo, G. S. and Stevens, R. G. 2002. Nitrogen recycling by nonleguminous winter cover crops to reduce leaching in potato rotations. Agron. J. 94: 365-372.

Wyland, L. J., Jackson, L. E., Chaney, W. E., Klonsky, K., Koike, S. T. and Kimple, B. 1996. Winter cover crops in a vegetable cropping system: Impacts on nitrate leaching, soil water, crop yield, pests and management costs. Agric. Ecosyst. Environ. 59: 1-17. 